\title{
The importance of the bioactive compounds of avocado fruit (Persea americana Mill) on human health
}

\author{
Importancia de los compuestos bioactivos del fruto de aguacate (Persea americana Mill) \\ en la salud humana
}

\begin{abstract}
Ana L. Ramos-Aguilar', Juan Ornelas-Paz' , Luis M. Tapia-Vargas², Saul Ruiz-Cruz³, Alfonso A. Gardea-Béjar, Elhadi M. Yahia $^{5}$, José de Jesús Ornelas-Paz ${ }^{1, *}$, Jaime D. Pérez-Martínez ${ }^{6}$, Claudio Rios-Velasco ${ }^{1}$, Vrani Ibarra-Junquera ${ }^{7}$

1 Centro de Investigación en Alimentación y Desarrollo A.C.-Unidad Cuauhtémoc. Av. Río Conchos S/N, Parque Industrial, C.P. 31570, Cd. Cuauhtémoc, Chihuahua, México.

2 Instituto Nacional de Investigaciones Forestales, Agrícolas y Pecuarias. Av. Latinoamericana No. 1101, Col. Revolución, CP. 60500, Uruapan, Michoacán, México.

3 Instituto Tecnológico de Sonora, Departamento de Biotecnología y Ciencias Alimentarias. 5 de Febrero 818 Sur, C.P. 85000 , Cd. Obregón, Sonora, México.

4 Centro de Investigación en Alimentación y Desarrollo A.C.-Unidad Guaymas, Carretera al Varadero Nacional Km. 6.6, Col. Las Playitas, C.P. 85480, Guaymas, Sonora, México.

5 Universidad Autónoma de Querétaro, Facultad de Ciencias Naturales. Avenida de las Ciencias S/N, C.P. 76230, Juriquilla, Querétaro, México.

6 Universidad Autónoma de San Luis Potosí, Facultad de Enfermería, Av. Niño Artillero No. 130, Zona Universitaria, C.P. 78210, San Luis Potosí, México.

7 Universidad de Colima, Laboratorio de Bioingeniería, Km. 9 carretera Coquimatlán-Colima, C.P. 28400, Coquimatlán, Colima, México.
\end{abstract}

\section{ABSTRACT}

Mexico is the largest producer, exporter and consumer of avocados (Persea americana Mill) in the world. The demand for this fruit in some non-producing countries is currently high. The main motivation for this fruit's consumption is its exquisite taste and pleasant texture. However, recent research has suggested that this fruit can exert protective effects on human health, as empirically determined centuries ago by the inhabitants of pre-Hispanic Mexico. These effects have been attributed to the high content of health-related compounds, including unsaturated fatty acids, acetogenins, phytosterols, tocopherols, tocotrienols, carotenoids, chlorophylls, phenols, organic acids and sugars of seven carbons. Avocado is one of the few fruits in the human diet with a high content of both water-soluble and fat-soluble health-related compounds. The main protective effects attributed to avocados include the prevention of cardiovascular diseases, diabetes and some forms of cancer, which are diseases considered in many countries as public health problems. Unfortunately, there is little research demonstrating the protective effects of avocados on human health. The aim of this work was the systematical analysis of the health-protective effects, both objectively regarded to avocado fruit, as well as those inferred from the avocado chemical composition.

Keywords: Nutrients; Phytochemicals; Antioxidants; Nutraceutical; Disease prevention.

\section{RESUMEN}

México es el principal productor, exportador y consumidor de aguacate (Persea americana Mill) en el mundo. La demanda actual de esta fruta en algunos países no pro- ductores es también alta. El consumo de esta fruta ha sido históricamente motivado por su exquisito sabor y textura agradable. Sin embargo, investigaciones recientes han sugerido que esta fruta podría ejercer un efecto protector en la salud, como empíricamente lo determinaron los habitantes del México prehispánico. Estos efectos se han atribuido a su alto y diverso contenido de compuestos protectores de la salud, incluyendo ácidos grasos insaturados, acetogeninas, fitoesteroles, tocoferoles, tocotrienoles, carotenoides, clorofilas, fenoles, ácidos orgánicos y azúcares de siete carbonos. El aguacate es una de las pocas frutas de la dieta que presenta un contenido alto de compuestos protectores de la salud tanto hidrosolubles como liposolubles. Entre los principales efectos protectores de la salud atribuidos al aguacate destacan la prevención de enfermedades cardiovasculares, diabetes y algunas formas de cáncer, padecimientos que están catalogados en muchos países como problemas de salud pública. No obstante, el aguacate ha sido escasamente estudiado en cuanto a su contribución en la salud humana. El objetivo del presente trabajo consistió en analizar sistemáticamente los efectos protectores de la salud atribuidos objetivamente al aguacate, así como los inferidos a partir de su composición química.

Palabras clave: Nutrientes; Fitoquímicos; Antioxidantes; Nutracéuticos; Prevención de enfermedades.

\section{INTRODUCTION}

The avocado (Persea Americana Mill) is a member of the plant family Lauraceae. The word "avocado" comes from the Nahuatl term "ahuacatl", which means testicle. The avocado originated in the mountainous areas located between

*Autor para correspondencia: José de Jesús Ornelas-Paz Correo electrónico: jornelas@ciad.mx Recibido: 29 de enero de 2019 Aceptado: 4 de junio de 2019 
Mexico and Guatemala. The oldest evidence found in Mexico of avocado consumption, was in Tehuacan, Puebla (Mexico), from 8000 to 7000 B.C. For decades, Mexico has been the largest avocados producer, exporter and consumer in the world (Yahia and Woolf, 2011; Villa-Rodríguez et al., 2012). The per-capita consumption of avocado in Mexico is about $7 \mathrm{~kg}$. However, the demand for this fruit has continuously increased in many non-producing countries, especially Japan, Canada and European countries like France, Netherlands and England, where the current per-capita consumption is below $1 \mathrm{~kg}$. In general, avocados are mainly consumed fresh (alone or accompanied with other foods), although in some countries it is fried or baked. The guacamole is a traditional Mexican dish and represents the most common form of avocado consumption. It is prepared by mixing avocado pulp with lime juice, salt and other ingredients, depending on the area. Avocados are also ingredients of salads, cakes, soups, desserts, ice cream and refreshing beverages. Frozen guacamole and avocado slices are very popular in nonproducing countries. Currently, avocado oil is very popular in the market, for use in gourmet cuisine or as a raw material for the manufacture of cosmetics (i.e. body/facial creams, shampoos, soaps and lipsticks).

Avocados contain significant quantities of nutrients, especially oil (20\%,w/w), minerals (potassium, phosphorus, calcium, magnesium) and vitamins of the B-complex, such as niacin, pyridoxine, riboflavin, thiamine, and biotin (Yahia and Woolf, 2011). They have a low sugar content, making them a suitable food for diabetics. Additionally, avocados are rich in some low molecular weight compounds like unsaturated fatty acids, acetogenins, phytosterols, phytostanols, chlorophylls, carotenoids, tocopherols, tocotrienols, phenolic compounds, organic acids and sugars of seven carbon atoms (Table 1 and Figure 1), which prevent some chronic diseases. The content of these compounds depends on avocado genotype, ripening stage, harvest date and several biotic and abiotic factors (Meyer et al., 2011). Based on the content of these human-health related compounds but with a limited number of studies with avocados, several beneficial properties have been attributed to this fruit, including the prevention of cardiovascular diseases, diabetes and some cancer forms, which are considered as public health problems in Mexico and other countries. According to Table 2, the main mechanisms associated to the protective effects caused by avocado, include the reduction of oxidative stress and lipid oxidation, induction of the expression of some genes, decrease in lipoprotein lipase activity, reduction in fat deposition in adipose tissue, and decrease of total cholesterol and triglycerides. The consumption of avocados contributes to the feeling of satiety and, therefore, to body weight loss (Tabeshpour et al., 2017). To date, many of these effects have not been clearly demonstrated, but inferred based on the chemical composition of avocados, which has not been completely determined yet. The aim of this work was the systematical analysis of the health-protective effects, both objectively regarded to avocado fruit, as well as those inferred from the
Table 1. Content of human-health related compounds in avocado pulp. Tabla 1. Concentración de compuestos protectores de la salud humana en la pulpa aguacate.

\begin{tabular}{|c|c|}
\hline Compound & Concentration (g/kg FW*) \\
\hline \multicolumn{2}{|l|}{ Fatty acids } \\
\hline Oleic & $2.42-2.98$ \\
\hline Linoleic & $0.37-0.50$ \\
\hline Palmitic & $0.29-0.45$ \\
\hline Palmitoleic & $0.14-1.3$ \\
\hline Linolenic & $0.07-0.12$ \\
\hline \multicolumn{2}{|l|}{ Acetogenins } \\
\hline Persenone A & $0.2-4.6$ \\
\hline Persin & $0.05-1.3$ \\
\hline \multicolumn{2}{|l|}{ Phytosterols } \\
\hline Sitosterol & $0.62-0.76$ \\
\hline Campesterol & $0.04-0.05$ \\
\hline Avenasterol & 0.04 \\
\hline Stigmasterol & $0.003-0.003$ \\
\hline \multicolumn{2}{|l|}{ Phytostanols** } \\
\hline Cycloartenol & 0.437 \\
\hline Sitostanol & 0.021 \\
\hline Campestanol & 0.004 \\
\hline \multicolumn{2}{|l|}{ Tocopherols** } \\
\hline$a-$ & $0.034-0.055$ \\
\hline$\delta-$ & $0.012-0.024$ \\
\hline$\beta-+\gamma^{-}$ & $0.006-0.067$ \\
\hline \multicolumn{2}{|l|}{ Tocotrienols** } \\
\hline$a-$ & 0.005 \\
\hline$\delta-$ & 0.008 \\
\hline$\beta-+\gamma^{-}$ & 0.009 \\
\hline \multicolumn{2}{|l|}{ Carotenoids } \\
\hline Lutein & $0.001-0.004$ \\
\hline$\beta$-carotene & $0.0005-0.0008$ \\
\hline a-carotene & $0.0002-0.0003$ \\
\hline$\beta$-cryptoxanthin & $0.0002-0.0003$ \\
\hline Zeaxanthin & 0.0002 \\
\hline Chlorophyll ( $a$ and $b$ ) & 0.19 \\
\hline \multicolumn{2}{|l|}{ Sugars } \\
\hline Mannoheptulose & $0.31-6.55$ \\
\hline Perseitol & $0.13-7.48$ \\
\hline Sucrose & $1.00-4.94$ \\
\hline Fructose & $0.15-2.48$ \\
\hline Glucose & $0.46-2.48$ \\
\hline \multicolumn{2}{|l|}{ Organic acids } \\
\hline Succinic & $0.01-0.18$ \\
\hline Ascorbic & 0.11 \\
\hline Quinic & $0.0002-0.06$ \\
\hline Citric & 0.009 \\
\hline \multicolumn{2}{|l|}{ Phenolic compounds } \\
\hline$p$-coumaric acid & $0.003-0.032$ \\
\hline Epicatechin & $0.00003-0.016$ \\
\hline Quercetin & $0.0-0.008$ \\
\hline
\end{tabular}

*FW, fresh weight. ${ }^{* *}$ In avocado oil. Data taken from: Duester, 2001; Liu et al., 2002; Piironen et al., 2003; Lu et al., 2005; Ashton et al., 2006; Cerretani et al., 2010; Meyer and Terry 2010; Hurtado-Fernández et al., 2011; Villa-Rodríguez et al., 2011; Yahia and Woolf, 2011; Berasategi et al., 2012; Blakey et al., 2012; Hurtado-Fernández et al., 2014; Rodríguez-López et al., 2015; López-Cobo et al., 2016. 


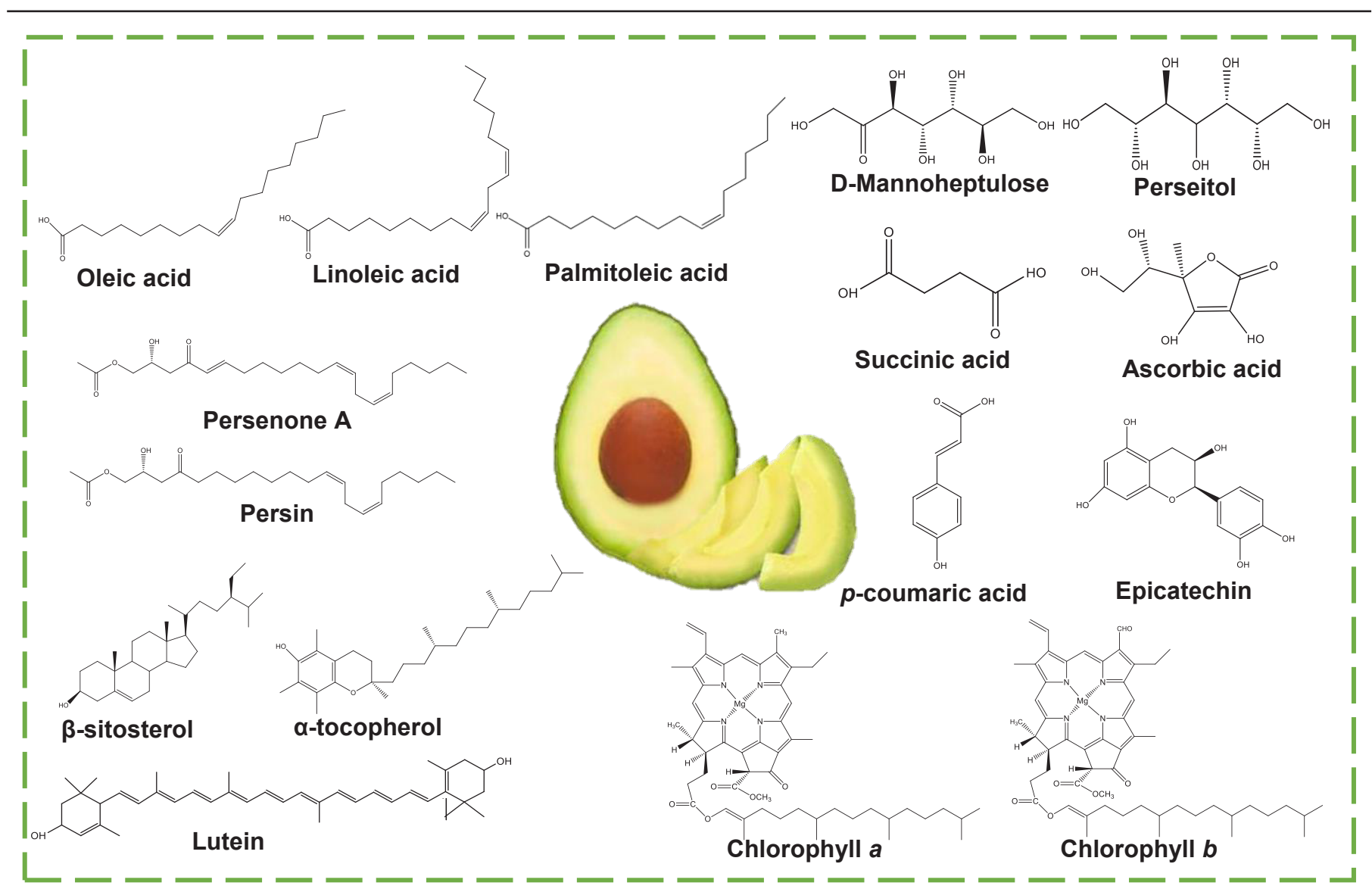

Figure 1. Main health-related compounds in avocado.

Figura 1. Principales compuestos protectores de la salud en el aguacate.

chemical composition of avocados. This review fill an existing gap of information in this regard.

\section{HUMAN-HEALTH RELATED COMPOUNDS OF AVOCADO FRUIT \\ Fatty acids}

The oil represents the main energy component in avocado fruit and favors the intestinal absorption of healthrelated compounds of lipid-soluble nature. In spite of this beneficial effect of avocado oil, a moderate consumption of this fruit is necessary because fat must not represent more than $20-30 \%$ of total calories of diet. The benefits of avocado consumption on human health have been mainly related to the high content of unsaturated fatty acids in this fruit. The oleic acid represents up to $60 \%$ of total fatty acid content in avocados (Table 1). Other unsaturated fatty acids in avocado fruits are linoleic, palmitoleic and linolenic acids. Some studies have demonstrated that the consumption of oleic acid caused a reduction of blood pressure. Terés et al. (2008) observed that oleic acid regulated the structure of membrane lipids and controlled signaling mediated by $\mathrm{G}$ protein, reducing blood pressure. Tan et al. (2018) recently observed that the ingestion of virgin avocado oil and simvastatin caused a decrease in the atherogenic index in rats and an increase in total cholesterol, reducing the risk for atherosclerosis. On the other hand, palmitoleic acid consumption could be useful for hypertriglyceridemia treatment, since it decreases levels of circulating triglycerides, low density lipoproteins (LDL) and high-sensitivity C-reactive protein, and increases high density lipoprotein (HDL) levels (Bernstein et al., 2014). Yang et al. (2011) observed that palmitoleic acid consumption avoided the increase of body weight and controlled the development of hyperglycemia, hypertriglyceridemia and insulin sensitivity in diabetic mice due to the suppression of proinflammatory gene expression. It also improves liver lipid metabolism.

\section{Acetogenins}

Acetogenins are fatty acid derivatives that typically contain an aliphatic chain of odd number carbon atoms and an acetoxy group with two additional carbons. They are biosynthesized in avocado fruit idioblasts (spheroid bodies where oil is stored) using triglycerides as precursors (Rodríguez-López et al., 2017). These compounds are classified according to the number of carbons in their deacetoxylated skeletons. Generically, they are named as Lauraceous acetogenins, a family composed by avocatins, pahuatins and persenins of 17,19 and 21 carbon atoms, respectively (Rodríguez-López et al., 2017). There is little information about these compounds. The most abundant acetogenins in avocados are persenone $A$ and persenin, which belong to the persenin group. The acetogenin content varies with the avocado variety and tissue type. Persenone $A$ is most abun- 
Table 2. Effects of avocado consumption on health.

Tabla 2. Efectos del consumo de aguacate en la salud.

\begin{tabular}{|c|c|c|}
\hline Avocado sample & Experimental model-Dose & Effect \\
\hline Oil & SID rats $-1 \mathrm{~mL} / 250 \mathrm{~g} \mathrm{BW} /$ day (12 months) & $\downarrow$ Blood glucose, $\uparrow$ total glutathione (RM), $\downarrow$ ROS production (RM), $\downarrow$ LP (RM). \\
\hline Oil & $\begin{array}{l}\text { Sucrose-induced diabetic rats-Food with } \\
0-30 \% \text { oil /day ( } 2 \text { months) }\end{array}$ & $\downarrow$ Glucose tolerance, $\downarrow$ insulin resistance, $\downarrow$ body weight. \\
\hline Oil & SID rats $-4 \mathrm{~mL} / \mathrm{kg}$ BW/day (3 months) & $\downarrow$ Mitochondrial dysfunction, $\uparrow$ complex III activity, $\downarrow$ ROS production, $\uparrow$ GSH/GSSG ratio. \\
\hline Oil & SID rats-1 mL/250 g BW/day (3 months) & $\begin{array}{l}\uparrow \text { Body weight (control rats), } \downarrow \text { weight loss (SID rats), } \downarrow \text { cholesterol, } \downarrow \text { TG, } \downarrow \text { oxidative } \\
\text { stress (LM), } \downarrow \text { LP (LM), } \downarrow R O S \text { (LM). }\end{array}$ \\
\hline $\begin{array}{l}\text { Hydro-methanolic } \\
\text { extract of pulp }\end{array}$ & SID rats -300 mg/kg BW/day (28 days). & $\begin{array}{l}\uparrow \text { Body weight, } \uparrow \text { insulin and glycogen, } \uparrow \text { hexokinase and G6PD activities, } \downarrow \text { fasting } \\
\text { blood glucose, } \downarrow \text { glycosylated Hb, } \downarrow \text { AST, } \downarrow \text { ALT. }\end{array}$ \\
\hline $\begin{array}{l}\text { Ethanolic extract of } \\
\text { pulp }\end{array}$ & SID rats-300 mg/kg BW/day (4 weeks). & $\begin{array}{l}\uparrow \text { Blood insulin levels, } \uparrow \text { Hb, } \downarrow \text { blood glucose levels, } \downarrow \text { glycosylated Hb, } \downarrow \text { blood urea, } \\
\downarrow \text { serum creatinine, } \downarrow \text { AST, } \downarrow \text { ALT, } \downarrow \text { ALP. }\end{array}$ \\
\hline $\begin{array}{l}\text { Mannoheptulose/ } \\
\text { pulp }\end{array}$ & $\begin{array}{l}\text { Animals/Humans- } 0.2-4 \mathrm{~g} / \mathrm{kg} \mathrm{BW} / 33-200 \\
\mathrm{mg} / \mathrm{kg} \mathrm{BW} \text {. }\end{array}$ & $\downarrow$ Glucose, $\downarrow$ insulin. \\
\hline Virgin oil & $\begin{array}{l}\mathrm{HCD} \text { rats }-450 \text { and } 900 \mathrm{mg} / \mathrm{kg} \mathrm{BW} / \text { day ( } 4 \\
\text { weeks). }\end{array}$ & $\downarrow L D L, T G, H D L, A L T, A S T$ and ALP. \\
\hline $\begin{array}{l}\text { Hydro-alcoholic ex- } \\
\text { tract of pulp }\end{array}$ & HFD rats-100 mg/kg BW/day (11 weeks). & $\begin{array}{l}\downarrow \text { Gene expression for FGF } 21, \downarrow \text { body mass index, } \downarrow \text { adiposity index, } \downarrow \text { total fat pad } \\
\text { mass, } \downarrow \text { cholesterol, TG and LDL, } \downarrow \text { leptin, } \downarrow \text { mRNA expression for fatty acid synthase, } \\
\downarrow \text { lipoprotein lipase. }\end{array}$ \\
\hline Pulp & $\begin{array}{l}\text { Obese or overweight humans-1 avoca- } \\
\text { do/day ( } 5 \text { weeks). }\end{array}$ & $\downarrow$ Cholesterol, LDL, LDL/HDL, apoliproteins and insulin. \\
\hline $\begin{array}{l}\text { Ethanolic extract of } \\
\text { pulp }\end{array}$ & HCD rats-300 mg/kg BW/day (4 weeks). & $\downarrow T G$, phospholipids, urea, creatinine, uric acid and LP. \\
\hline Fresh/defatted pulp & HCF-2 g/kg BW/day (7 weeks). & $\downarrow$ Cholesterol, TG, LDL, AST and ALT. \\
\hline Pulp & $\begin{array}{l}\text { Overweight humans-Half avocado/day } \\
\text { ( } 3 \text { days). }\end{array}$ & $\uparrow$ Leptin, $\downarrow$ insulin, $\downarrow$ glucagon-like peptide- 1 levels, $\downarrow$ satiety. \\
\hline $\begin{array}{l}\text { Mannoheptulose/ } \\
\text { pulp }\end{array}$ & $\begin{array}{l}\text { Human tumor cells/animals- } 100 \mu \mathrm{L} \text { of } 1.7 \\
\mathrm{mg} / \mathrm{g} \text { BW/day ( } 5 \text { days). }\end{array}$ & $\downarrow$ Glucose uptake and growth rate. \\
\hline $\begin{array}{l}\text { Acetone extract of } \\
\text { pulp }\end{array}$ & Prostate tumor cells -300 and $100 \mu \mathrm{L} / \mathrm{mL}$. & $\downarrow$ Proliferation in androgen-dependent and independent lines. \\
\hline Oil & $\begin{array}{l}\text { Animals/Otic hair cells-10 } \mu \mathrm{g} / \mathrm{mL}(8 \mathrm{~h}) \\
100-300 \mathrm{mg} / \mathrm{kg} \text { BW/day ( } 20 \text { days). }\end{array}$ & $\begin{array}{l}\downarrow \text { Gene expression altered by oxidative stress, production of cytokinins and protein } \\
\text { synthesis pathways altered by neomycin. }\end{array}$ \\
\hline Pulp & $\begin{array}{l}\text { Healthy humans }-1 \text { avocado /day ( } 6 \\
\text { months). }\end{array}$ & $\uparrow \mathrm{HDL}, \downarrow \mathrm{LDL}, \downarrow \mathrm{TG}, \uparrow$ serum lutein levels, $\uparrow$ macular pigment density, $\uparrow$ cognitive health. \\
\hline Pulp & $\begin{array}{l}\text { Healthy overweight humans- } 200 \mathrm{~g} / \mathrm{day} \\
\text { ( } 6 \text { weeks). }\end{array}$ & $\uparrow$ Circulating oleic acid, $\downarrow$ circulating myristic acid. \\
\hline Pulp or oil & $\begin{array}{l}\text { Healthy humans- } 75-150 \mathrm{~g} \text { or } 24 \mathrm{~g} \text { of oil / } \\
\text { day ( } 8 \text { weeks). }\end{array}$ & $\uparrow A b s o r p t i o n$ of $\beta$-carotene, $a$-carotene, lycopene and lutein. \\
\hline
\end{tabular}

BW= Body weight, $\mathrm{SID}=$ Streptozotocin-Induced Diabetic, $\mathrm{HCD}=$ Hipercolesterolemic Diet, HFD= High Fat Diet, ROS= Reactive Oxygen Species, $\mathrm{LP}=\mathrm{Lipid}$ Peroxidation, RM= Renal Mitochondria, LM= Liver Mitochondria, GSH/GSSG= Reduced Glutathione/Oxidized Glutathione, LM=Liver Mitochondria, TG= Triglyceride, G6PD= Glucose-6-Phosphate dehydrogenase, $\mathrm{Hb}=$ Hemoglobin, LDL=Low Density Lipoprotein, $\mathrm{HDL}=$ High Density Lipoprotein, ALT= Alanine transaminase, AST= Aspartate transaminase, ALP= Alkaline Phosphatase, FGF21= Fibroblast growth factor-21. Data taken from: Viktora et al., 1969; Board et al., 1995; Lu et al., 2005; Pieterse et al., 2005; Unlu et al., 2005; Rao and Adienew, 2011; Thenmozhi et al., 2012; Mahadeva Rao et al., 2014; Pahua-Ramos et al., 2014; Monika and Geetha, 2015; Ortiz-Avila et al., 2015a; Ortiz-Avila et al., 2015b; Sabatéj et al., 2015; Wang et al., 2015; Del Toro-Equihua et al., 2016; Ortiz-Avila et al., 2017; Scott et al., 2017; Tan et al., 2018; Nam et al. 2019.

dant in the avocado peel and pulp, representing 46 and $48 \%$ of total acetogenins in these tissues, respectively. However, some studies have demonstrated that persin is the most abundant acetogenin in some avocado cultivars (RodríguezLópez et al., 2015).
Currently, the bioavailability of avocado acetogenins is unknown but some studies have revealed that these compounds might exert some protective effects on human health. Acetogenins show high antioxidant activity, mainly inhibiting the production of nitric oxide and superoxide in 
cells. They also exert pro-apoptotic activity in cancer cells and protect against acute myeloid leukemia (Rodríguez-López et al., 2015). Lauraceous acetogenins exert antiplatelet activity, preventing thrombi formation. In humans, persenone $A$ at a dose of $25 \mathrm{mg} / \mathrm{kg}$ body weight attenuates the formation of thrombi. In vitro studies showed that persenone $\mathrm{C}$ had a more potent antiplatelet activity than other acetogenins (1-acetoxy-2,4-dihydroxy-n-heptadeca-16-ene, persediene, persenone-A, persenone-B, persin and 1- acetoxy-2,4-dihydroxy-heneicosa-12,15-diene). The structure of persenone $C$ contains an omega- 3 unsaturation, which is similar to that of some fatty acids recognized for their cardioprotective effect, inferring that persenone $C$ also exert such effect (RodríguezSánchez et al., 2015). Further studies are needed to understand the biosynthetic pathway of avocado acetogenins and their effects on human health.

\section{Phytosterols and phytostanols}

These compounds are fat-soluble. The main phytosterols of avocado pulp are $\beta$-sitosterol, campesterol and stigmasterol. The main phytostanol is cycloarthenol. Other phytosterols and phytostanols reported in avocado oil are campestanol, lanosterol, $\Delta 5$-avenasterol, $\Delta 7$-sitoesterol, citrostadienol, cycloeucalenol and 24-methylenecycloartanol (Piironen et al., 2003; Berasategi et al., 2012). The recommended dose of phytosterols and phytostanols is 2 $\mathrm{g} /$ day, with higher doses reducing the absorption of other lipid-soluble compounds, such as $\beta$-carotene, lycopene and a-tocopherol (López, 2005). Phytosterols and phytostanols reduce the intestinal absorption of cholesterol and, consequently, the circulating level of this lipid, effect mediated by the activation of genes regulated by co-activating peptides of the liver $\mathrm{X}$ receptor. Additionally, phytosterols and phytostanols compete with cholesterol for absorption (Tan et al., 2018). The $\beta$-sitosterol also interrupts the recirculation of bile acids during digestion, reducing the intestinal absorption of cholesterol by compromising cholesterol micellarization and, consequently, reducing the risk of infarction, atherosclerosis, thrombosis and other cardiovascular diseases where the circulating cholesterol level is an important causal or predisposition factor (Bin et al., 2016). The reduction of cholesterol absorption by phytosterols and phytostanols can lead to a compensatory increase in the biosynthesis of cholesterol and expression of LDL receptors with the concomitant decrease in levels of circulating LDL (Tan et al., 2018). Some studies suggest that $\beta$-sitosterol prevents the formation of gallstones, reduces hepatic cholesterol and influences the endocrine and reproductive systems; however, more studies are necessary to verify these protective effects. The $\beta$-sitosterol can also act as an antipyretic, exerting a similar effect than that of the acetylsalicylic acid (Bin et al., 2016).

Stigmasterol can reduce the circulating levels of triiodothyronine, thyroxine and glucose as well as the activity of glucose-6-phosphatase in liver, with an increase of insulin. This phytosterol exerts antioxidant properties by a decrease in liver lipid peroxidation and an increase in catalase, super- oxide dismutase and glutathione reductase activity (Saeidnia et al., 2014). The consumption of phytosterols has also been associated with the prevention of various cancer forms. The $\beta$-sitosterol promotes apoptosis in breast cancer cells (MDAMB-231) and inhibits tumor growth, and inhibits colon cancer cells (HT-29 cells) proliferation. Daucosterol ( $\beta$-sitosterol glycoside) is more active against K-562 cells (leukemia). Campesterol probably exerts an anti-angiogenic action, helping in the treatment of cancer (Saeidnia et al., 2014). The $\beta$-sitosterol inhibits production and expression of mRNA for thymic stromal lymphopoietin by blocking the caspase-1 and the nuclear factor-kB signaling pathways in human cell lines, demonstrating a potential use of this compound in the atopic dermatitis treatment. For these reasons, $\beta$-sitosterol has been used as an ingredient in sun creams and moisturizers, bath gels and other cosmetic products (Bin et al., 2016).

\section{Tocopherols and tocotrienols}

Tocopherols and tocotrienols are fat-soluble compounds. The avocado pulp is rich in a-tocopherol but also contains small concentrations of $\gamma$ - and $\delta$-tocopherol. All tocopherols and tocotrienols are potent scavengers of lipoperoxyl radicals, however, a-tocopherol is the most studied in this regard (Cerretani et al., 2010). This tocopherol property allows it to intercept peroxyl radicals participating in the chain reaction of lipid oxidation in cell membranes and LDL, with these actions playing an important role in cholesterol transport from the liver to body tissues. The oxidation of LDL is associated with the development of cardiovascular diseases due to lipid deposition in the arterial wall (Saini and Keum, 2016). The a-tocopherol is one of the most potent antioxidants that exist in the nature. Tocopherols and tocotrienols reduce the risk of several cancer forms (lung, esophagus, stomach, skin and large intestine). The $a-$ and $\gamma$-tocopherol inhibit the growth of PC-3 and LNCaP cells ( $\mathrm{Lu}$ et al., 2005). Tocopherols and tocotrienols strengthen the immune system, relieve inflammatory diseases (arthritis, rheumatoid arthritis and osteoarthritis) symptoms, and prevent cataracts and age-related macular degeneration. This group of compounds can protect against neurological disorders (Alzheimer's and Parkinson's) and aging (Ornelas-Paz et al., 2012).

\section{Carotenoids}

Lutein is the most abundant carotenoid in avocado pulp, which also contains $\beta$-cryptoxanthin, zeaxanthin, a-carotene and $\beta$-carotene. Lu et al. (2005) demonstrated that the lutein content in 'Hass' avocados represented $70 \%$ of total carotenoids. The concentration of carotenoids is greater in the avocado peel than in the pulp, with lutein being the main carotenoid in both tissues. The avocado pulp of darkgreen color has a higher concentration of carotenoids, up to 1.8 times higher, than that of pulp of pale green or yellow color (Ashton et al., 2006). The high oil content of avocados favors absorption of carotenoids and other lipid soluble compounds (Unlu et al., 2005). 
Carotenoids are effective deactivators of free radicals in human cells. This property, determined by physical and chemical processes, prevents the development of several degenerative diseases. Carotenoids participate in cell signaling, influencing gene expression and inhibiting enzymes involved in the pathogenesis of some diseases. Carotenoids prevent several cancer forms (lung, prostate, liver, breast, skin, etc.) (Yahia and Ornelas-Paz, 2010). The protective effect of carotenoids on cardiovascular diseases prevention is unclear. Lutein and zeaxathin protect the eye against some pathologies, including cataracts and age-related macular degeneration. Carotenoids protect the skin from sun exposure damage, and several of them ( $\beta$-carotene, $\alpha$-carotene and $\beta$-cryptoxanthin) are precursors of vitamin A (Ornelas-Paz et al., 2012).

\section{Chlorophyll}

Chlorophyll confers the green color to the pulp and peel of avocados. The chlorophyll content in these tissues is 2.2-38 and $186 \mu \mathrm{g} / \mathrm{g}$, respectively (Ashton et al., 2006). Chlorophyll is highly unstable in foods, leading to the formation of pheophytins, pyropheophytins, chlorophyllide, chlorins and metallochlorophilic complexes of pheophytin $a$ and pyropheophytin. These chlorophyll derivatives are involved in fat and oil oxidation but in dark environments, the chlorophyll and chlorophyll derivatives show antioxidant properties in oils (Ornelas-Paz et al., 2012).

Several studies have shown that chlorophyll and chlorophyll derivatives (pheophytins and pheophorbide) exert antimutagenic and antigenotoxic activities in bacteria and cell cultures. Natural chlorophyll and sodium copper chlorophyllin can exert protective effects against hepatocarcinogenesis, papillomagenesis and skin cancer in rainbow trout and mice. The consumption of chlorophyll-rich foods reduces the risk of colon cancer in humans. The anticancer effects of chlorophyll have been attributed to its antioxidant activity, ability to trap mutagens, modulatory effect on detoxification mechanisms and ability to induce cellular apoptosis (Ferruzzi y Blakeslee, 2007).

\section{Phenolic compounds}

Phenolic compounds are substances that contain one or more aromatic rings with one or more hydroxyl groups. They contribute to the pigmentation and astringency of fruits and vegetables. The avocado pulp is not an important source of phenolic compounds, as compared to peel and seed. Wang et al. (2010) found that the total phenolic content in pulp, peel and seed of 'Hass' avocados was 4.9, 12.6 and 51.6 $\mathrm{mg} / \mathrm{g}$, respectively. The main phenolic compounds of avocado pulp are $p$-coumaric acid, quercetin and epicatechin. The color change of peel during avocado ripening is determined by chlorophyll degradation and an increase in the synthesis of cyanidin 3-O-glucoside, an anthocyanin.

In general, phenolic compounds can significantly improve the condition of patients with cardiovascular diseases, mainly because of their antioxidant activity and involvement in the endogenous regulation of cholesterol biosynthesis. They can also reduce hypertension by promoting diuresis. These compounds exert hypoglycemic effects and prevent alterations in lipid metabolism, helping patients with diabetes mellitus (Havsteen, 2002). Phenolic compounds have shown a high activity against carcinomas of ectodermal (skin, breast, buccal epithelium, urogenital tract and lung), entodermic (gastrointestinal tract, mammary glands, gonads, uterus, prostate, colon and rectum) and mesodermal (blood cells, bone and muscle) origin. The anticancer effects of phenolic compounds can be attributed to their involvement on systems regulating growth, energy metabolism, apoptosis, cell division, transcription, gene repair, neuronal transmission, inflammation, and stress response. Phenolic compounds also exert high activity against bacteria, protozoa and infections caused by fungi. They also show antiallergenic and antiatherogenic properties. The consumption of phenols-rich foods has been associated to the prevention of Alzheimer's disease (Ornelas-Paz et al., 2012)

\section{Organic acids}

The organic acids commonly found in avocado pulp are succinic, citric, quinic and ascorbic acid (AA). Some of these acids are important because they are involved in the human body metabolism. Succinic acid promotes the absorption of iron in humans. Anemic male infants show lower succinate values than female anemic infants (McClorry et al., 2018). The protective effects of AA have widely been studied. The AA acts as enzymatic cofactor inactivating free radicals, and as donor/receptor in the electrons transport chain in the plasma membrane or chloroplasts. The biological importance of the AA antioxidant activity, as compared with that of other antioxidants of low molecular weight (a-tocopherol, carotenoids, flavonoids, etc.), is the ability of AA to end the free radicals chain reactions, converting them into products that are nontoxic without becoming itself in another radical. The AA reduces the oxidation of circulating lipids, including LDL. Several studies have shown that AA protects against oxidative stress-related diseases and age-related degeneration, including coronary heart disease, cataracts and several cancer forms. AA is also essential for collagen and carnitine synthesis, neuronal maturation and communication, learning, memory and locomotor activity. It participates in the normal functioning of fibroblasts, osteoblasts and immune system. The coexistence of AA and tocopherols in avocado makes this fruit an ideal food for people with hypercholesterolemia because the combination of these compounds reduces the progression rate of arteriosclerosis (Salonen et al., 2003).

\section{Sugars}

In contrast to many fruits, the avocado pulp contains small quantities of glucose, fructose and sucrose, making it suitable for persons with diabetes. One characteristic of avocados is the high content of seven carbon-atoms sugars, with D-mannoheptulose $(\mathrm{MH})$ and perseitol being the most abun- 
dant and characteristic of avocado fruit. The consumption of $\mathrm{MH}$ reduces the secretion of insulin and favors gluconeogenesis, protecting these effects against diabetes. The $\mathrm{MH}$ exerts a mimetic effect of caloric restriction, delaying aging and related ailments (Saraswat and Rizvi, 2017). The MH also reduces $(65-79 \%)$ the growth rate of malignant tumors possibly limiting the consumption of glucose by tumor cells (Board et al., 1995). On the other hand, perseitol can exert anticancer effects in animals by inhibiting protein synthesis in tumor cells. Avocado extracts rich in $\mathrm{MH}$ and perseitol can inhibit skin colonization by Malassezia furfur, a fungus that causes dandruff (Donnarumma et al., 2007).

\section{CONCLUSIONS}

Avocados are rich in nutrients and compounds that prevent chronic diseases, especially cardiovascular diseases, diabetes and some cancer forms. The 'Hass' avocados are the most studied in this regard, underestimating the wide diversity of avocado genotypes available in Mexico and another avocado-producing countries as functional food. It is important to determine the bioavailability of human-health related compounds of avocado fruit and confirm their protective effects on human health.

\section{ACKNOWLEDGEMENTS}

This work is part of the research project "Determinación de acil-transferasa y posibles genes involucrados en la esterificación de carotenoides, su potencial de absorción y actividad antioxidante en frutos de aguacate" (Clave A1-S-28359) funded by CONACYT.

\section{REFERENCES}

Ashton, O.B.O., Wong, M., McGhie, T.K., Vather, R., Wang, Y., Requejo-Jackman, C., Ramankutty, P. and Woolf, A.B. 2006. Pigments in avocado tissue and oil. Journal of Agricultural and Food Chemistry. 54: 10151-10158.

Berasategi, I., Barriuso, B., Ansorena, D. and Astiasarán, I. 2012. Stability of avocado oil during heating: Comparative study to olive oil. Food Chemistry. 132: 439-446.

Bernstein, A.M., Roizen, M.F. and Martinez, L. 2014. Purified palmitoleic acid for the reduction of high-sensitivity C-reactive protein and serum lipids: A double-blinded, randomized, placebo controlled study. Journal of Clinical Lipidology. 8: 612-617.

Bertling, I., Tesfay, S. and Bower, J. 2007. Antioxidants in 'Hass' avocado. South African Avocado Growers' Association Yearbook. 30: 17-19.

Bin Sayeed, M.S., Karim, S.M.R., Sharmin, T. and Morshed, M.M. 2016. Critical analysis on characterization, systemic effect, and therapeutic potential of beta-sitosterol: a plant-derived orphan phytosterol. Medicines. 3: 29.

Blakey, R.J., Tesfay, S.Z., Bertling, I. and Bower, J.P. 2012. Changes in sugars, total protein, and oil in 'Hass' avocado (Persea americana Mill.) fruit during ripening. The Journal of Horticultural Science and Biotechnology. 87: 381-387.

Board, M., Colquhoun, A. and Newsholme, E.A. 1995. High Km glucose-phosphorylating (glucokinase) activities in a range of tumor cell lines and inhibition of rates of tumor growth by the specific enzyme inhibitor mannoheptulose. Cancer Research. 55: 3278-3285.

Cerretani, L., Lerma-García, M.J., Herrero-Martínez, J.M., GallinaToschi, T. and Simó-Alfonso, E. F. 2010. Determination of tocopherols and tocotrienols in vegetable oils by nanoliquid chromatography with ultraviolet-visible detection using a silica monolithic column. Journal of Agricultural and Food Chemistry. 58: 757-761.

Del Toro-Equihua, M., Velasco-Rodríguez, R., López-Ascencio, R. and Vásquez, C. 2016. Effect of an avocado oil-enhanced diet (Persea americana) on sucrose-induced insulin resistance in Wistar rats. Journal of Food and Drug Analysis. 24: 350-357.

Donnarumma, G., Buommino, E., Baroni, A., Auricchio, L., Filippis, A.D., Cozza, V., Msika, P., Piccardi, N. and Tufano, M.A. 2007. Effects of AV119, a natural sugar from avocado, on Malassezia furfur invasiveness and on the expression of HBD-2 and cytokines in human keratinocytes. Experimental Dermatology. 16: 912-919.

Duester, K.C. 2001. Avocado fruit is a rich source of betasitosterol. Journal of The American Dietetic Association. 101: 404-405.

Ferruzzi, M.G., and Blakeslee, J. 2007. Digestion, absorption, and cancer preventative activity of dietary chlorophyll derivatives. Nutrition Research. 27: 1-12.

Havsteen B.H. 2002. The biochemistry and medical significance of the flavonoids. Pharmacology and Therapeutics. 96: 67202.

Hurtado-Fernández, E., Carrasco-Pancorbo, A. and FernándezGutiérrez, A. 2011. Profiling LC-DAD-ESI-TOF MS method for the determination of phenolic metabolites from avocado (Persea americana). Journal of Agricultural and Food Chemistry. 59: 2255-2267.

Hurtado-Fernández, E., Pacchiarotta, T., Mayboroda, O.A., Fernández-Gutiérrez A. and Carrasco-Pancorbo, A. 2014. Quantitative characterization of important metabolites of avocado fruit by gas chromatography coupled to different detectors (APCI-TOF MS and FID). Food Research International. 62: 801-811.

Liu, X., Sievert, J., Arpaia, M.L. and Madore, M.A. 2002. Postulated physiological roles of the seven-carbon sugars, mannoheptulose, and perseitol in avocado. Journal of the American Society for Horticultural Science. 127: 108-114.

López L.M.T. 2005. Fitoesteroles y fitoestanoles: su papel en la prevención cardiovascular. Offarm: Farmacia y Sociedad. 24: 90-94.

López-Cobo, A., Gómez-Caravaca, A.M., Pasini, F., Caboni, M.F., Segura-Carretero, A. and Fernández-Gutiérrez, A. 2016. HPLC-DAD-ESI-QTOF-MS and HPLC-FLD-MS as valuable tools for the determination of phenolic and other polar compounds in the edible part and by-products of avocado. LWT-Food Science and Technology. 73(Supplement C): 505513.

Lu, Q.-Y., Arteaga, J.R., Zhang, Q., Huerta, S., Go, V.L.W. and Heber, D. 2005. Inhibition of prostate cancer cell growth by an avocado extract: role of lipid-soluble bioactive substances. The Journal of Nutritional Biochemistry. 16: 23-30.

Mahadeva Rao, U., Ponnusamy, K., Naidu, J.R. and Sundaram, C.S. 2014. Modulatory influence of avocado on renal oxidolipidemic stress and mRNA expression of NOS in renal artery studied in nephropathy induced rats. International Medical Journal. 21:1-7. 
McClorry, S., Zavaleta, N., Llanos, A., Casapía, M., Lönnerdal, B. and Slupsky, C.M. 2018. Anemia in infancy is associated with alterations in systemic metabolism and microbial structure and function in a sex-specific manner: an observational study. The American Journal of Clinical Nutrition. 108: 1-11.

Meyer, M.D. and Terry, L.A. 2010. Fatty acid and sugar composition of avocado, cv. Hass, in response to treatment with an ethylene scavenger or 1-methylcyclopropene to extend storage life. Food Chemistry. 121: 1203-1210.

Meyer, M.D., Landahl, S., Donetti, M and Terry, L.A. 2011. 3 Avocado. In: Health-promoting Properties of Fruit and Vegetables. Terry L.A. (ed.), pp 27-50. CABI, United Kingdom.

Monika, P. and Geetha, A. 2015. The modulating effect of Persea americana fruit extract on the level of expression of fatty acid synthase complex, lipoprotein lipase, fibroblast growth factor-21 and leptin-a biochemical study in rats subjected to experimental hyperlipidemia and obesity. Phytomedicine. 22: 939-945.

Ornelas-Paz J.J., Yahia E.M. Gardea-Béjar A.A., Pérez-Martónez J.D., Ibarra-Junquera, V., Escalante-Minakata, M.P., RuizCruz S. and Ochoa-Reyes, E. 2012. Actividad antioxidante y protectora de selectos compuestos bioactivos de frutas y hortalizas. In: Antioxidantes en alimentos y salud. Álvarez Parrilla E., Gónzalez Aguilar G.A., de la Rosa L.A. y Ayala Zavala J.F. (eds.), pp 9-132. Clave editorial, México.

Ortiz-Avila, O., Gallegos-Corona, M.A., Sánchez-Briones, L.A., Calderón-Cortés, E., Montoya-Pérez, R., Rodríguez-Orozco, A.R., Campos-García, J., Saavedra-Molina, A., Mejía-Zepeda, R. and Cortés-Rojo, C. 2015a. Protective effects of dietary avocado oil on impaired electron transport chain function and exacerbated oxidative stress in liver mitochondria from diabetic rats. Journal of Bioenergetics and Biomembranes. 47: 337-353.

Ortiz-Avila, O., Esquivel-Martínez, M., Olmos-Orizaba, B.E., Saavedra-Molina, A., Rodríguez-Orozco, A.R., and CortésRojo, C. 2015b. Avocado oil improves mitochondrial function and decreases oxidative stress in brain of diabetic rats. Journal of Diabetes Research. 2015: 485759.

Ortiz-Avila, O., Figueroa-García M.C., García-Berumen, C.I., Calderón-Cortés, E., Mejía-Barajas, J.A., Rodríguez-Orozco, A.R., Mejía-Zepeda, R., Saavedra-Molina, A. and CortésRojo, C. 2017. Avocado oil induces long-term alleviation of oxidative damage in kidney mitochondria from type 2 diabetic rats by improving glutathione status. Journal of Bioenergetics and Biomembranes. 49: 205-214.

Pahua-Ramos, M.E., Garduño-Siciliano, L., Dorantes-Álvarez, L., Chamorro-Cevallos, G., Herrera-Martínez, J., Osorio-Esquivel, O. and Ortiz-Moreno, A. 2014. Reduced-calorie avocado paste attenuates metabolic factors associated with a hypercholesterolemic-high fructose diet in rats. Plant Foods Human Nutrition. 69: 18-24.

Pieterse, Z., Jerling, J.C., Oosthuizen, W., Kruger, H.S., Hanekom, S.M., Smuts, C.M. and Schutte, A. E. 2005. Substitution of high monounsaturated fatty acid avocado for mixed dietary fats during an energy-restricted diet: effects on weight loss, serum lipids, fibrinogen, and vascular function. Nutrition. 21: 67-75.

Piironen, V., Toivo, J., Puupponen-Pimiä, R. and Lampi, A.-M. 2003. Plant sterols in vegetables, fruits and berries. Journal of the Science of Food and Agriculture. 83: 330-337.
Rao, U.M. and Adinew, B. 2011. Remnant B-cell-stimulative and anti-oxidant effects of Persea americana fruit extract studied in rats introduced into streptzotocin-induced hyperglycaemic state. African Journal of Traditional, Complementary and Alternative Medicines. 8: 210-217.

Rodríguez-López, C.E., Hernández-Brenes, C. and de la Garza, R.I.D. 2015. A targeted metabolomics approach to characterize acetogenin profiles in avocado fruit (Persea americana Mill). Royal Society of Chemistry Advances. 5: 106019-106029.

Rodríguez-López, C.E., Hernández-Brenes, C., Treviño, V. and de la Garza, R.I.D. 2017. Avocado fruit maturation and ripening: dynamics of aliphatic acetogenins and lipidomic profiles from mesocarp, idioblasts and seed. BioMed Central Plant Biology. 17: 159.

Rodríguez-Sánchez, D.G., Flores-García, M., Silva-Platas, C., Rizzo, S., Torre-Amione, G., De la Peña-Diaz, A. HernándezBrenes, C. and García-Rivas, G. 2015. Isolation and chemical identification of lipid derivatives from avocado (Persea americana) pulp with antiplatelet and antithrombotic activities. Food \& Function. 6: 192-202.

Sabaté, J., Wien, M. and Haddad, E. 2015. Post-ingestive effects of avocados in meals on satiety and gastric hormone blood levels. Human Health Nutrition. 459-461.

Saeidnia, S., Manayi, A., Gohari, A.R. and Abdollahi, M. 2014. The story of beta-sitosterol-a review. European Journal of Medicinal Plants. 4: 590-609.

Saini, R.K., and Keum, Y.S. 2016. Tocopherols and tocotrienols in plants and their products: A review on methods of extraction, chromatographic separation, and detection. Food Research International. 82: 59-70.

Salonen, R.M., Nyyssönen, K., Kaikkonen, J., Porkkala-Sarataho, E., Voutilainen, S., Rissanen, T.H., Tuomainen, T.P., Valkonen, V.P., Ristonmaa, U. and Lakka, H.M. 2003. Six-year effect of combined vitamin $C$ and $E$ supplementation on atherosclerotic progression. Circulation. 107: 947-953.

Saraswat, K., and Rizvi, S.I. 2017. Novel strategies for anti-aging drug discovery. Expert Opinion on Drug Discovery. 12: 955966.

Scott, T.M., Rasmussen, H.M., Chen, O. and Johnson, E.J. 2017. Avocado consumption increases macular pigment density in older adults: a randomized, controlled trial. Nutrients. 9: 919.

Tabeshpour, J., Razavi, B.M., Hosseinzadeh, H. 2017. Effects of Avocado (Persea americana) on metabolic syndrome: a comprehensive systematic review. Phytotherapy Research. 31: 819-837.

Tan, C.X., Chong, G.H., Hamzah, H. and Ghazali, H.M. 2018. Hypocholesterolaemic and hepatoprotective effects of virgin avocado oil in diet-induced hypercholesterolaemia rats. International Journal of Food Science and Technology. 53: 2706-2713.

Terés, S., Barceló-Coblijn, G., Benet, M., Alvarez, R., Bressani, R., Halver, J.E. and Escriba, P.V. 2008. Oleic acid content is responsible for the reduction in blood pressure induced by olive oil. Proceedings of the National Academy of Sciences. 105: 13811-13816.

Thenmozhi, A., Shanmugasundaram, C. and Rao, U.M. 2012. Biochemical evaluation of anti-diabetic phytomolecule through bioactivity guided solvent fractionation and 
subfractionation from hydromethanolic (2:3) extract of Alligator pear Fruit in streptozotocin induced diabetic rats. Journal of Applied Pharmaceutical Science. 2: 61-69.

Unlu, N.Z., Bohn, T., Clinton, S.K. and Schwartz, S.J. 2005. Carotenoid absorption from salad and salsa by humans is enhanced by the addition of avocado or avocado oil. The Journal of Nutrition. 135: 431-436.

Viktora, J.K., Johnson, B.F., Penhos, J.C., Rosenberg, C.A. and Wolff, F.W. 1969. Effect of ingested mannoheptulose in animals and man. Metabolism-Clinical and Experimental. 18: 87-102.

Villa-Rodríguez, J.A., Molina-Corral, F.J., Ayala-Zavala, J.F., Olivas, G.I. and González-Aguilar, G.A. 2011. Effect of maturity stage on the content of fatty acids and antioxidant activity of 'Hass' avocado. Food Research International. 44: 1231-1237.

Wang, W., Bostic, T.R. and Gu, L. 2010. Antioxidant capacities, procyanidins and pigments in avocados of different strains and cultivars. Food Chemistry. 122: 1193-1198.
Wang L., Bordi P.L., Fleming, J.A., Hill, A.M. and Kris-Etherton, P.M. 2015. Effect of a moderate fat diet with and without avocados on lipoprotein particle number, size and subclasses in overweight and obese adults: a randomized, controlled trial. Journal American Heart Association. 4: e001355.

Yahia, E.M. and Ornelas-Paz, J.D.J. 2010. Chemistry, stability and biological actions of carotenoids. In: Fruit and Vegetable Phytochemicals: Chemistry, Nutritional Value, and Stability. L.A. de la Rosa, E. Alvarez-Parrilla, and G.A. González-Aguilar (Eds.), pp 177-222. Blackwell Publishing, United States.

Yahia, E.M. and Woolf, A.B. 2011. Avocado (Persea Americana Mill.). In: Postharvest biology and technology of tropical and subtropical fruits, Vol 2. E.M. Yahia (ed.), pp 125-186. Woodhead Publishing. Oxford, England.

Yang, Z.H., Miyahara, H. and Hatanaka, A. 2011. Chronic administration of palmitoleic acid reduces insulin resistance and hepatic lipid accumulation in KK-A y Mice with genetic type 2 diabetes. Lipids in Health and Disease. 10: 120. 